\title{
The Role of Institutional Framework and Technology on Food Security in Short and Long-Term in Indonesia: Autoregressive Distributed Lag Approach
}

\author{
Rodhiah Umaroh ${ }^{1}$ \\ Rahmi Budhy Fatmasari² \\ Faculty of Economics and Business, Universitas Gadjah Mada, Special Region of \\ Yogyakarta
}

\begin{abstract}
The agricultural sector has been given the largest contribution in economy Indonesia. Besides being able to absorb large numbers of workers, the agricultural sector also has an important role in reducing poverty vulnerability in rural households. This study aims to analyze the role of institutions and technological use in food security which proxied by the food production index in Indonesia, both in the short and long term. The analytical technique for estimating short-term and long-term relationships in this study is the Autoregressive Distributed Lag (ARDL) model using time series data from 19782014. The results showed that in the short term land availability, technological use in technology (tractor machines) and the availability of electricity had a positive and significant effect on food production in Indonesia. Whereas in the long term, land availability and GDP per capita are positive and significantly enhances food security. In addition, the institutional framework proxied by political rights and civil liberties has a significant positive and negative effects in the long term. Variable land availability is the biggest factor in increasing food security in Indonesia so that a policy that effectively regulates agricultural land use needs to be made. Interaction between the society, farmers and the government is also needed to create synergies and contributions related to food production. The provision of social security to farmers, especially when there is a shock, and the policy of procurement of agricultural technology must also be considered to maintain national food security in the long run.
\end{abstract}

Keywords: agricultural technology, ARDL, food security, institutional, agricultural technology

\footnotetext{
${ }^{1}$ Rodhiah Umaroh is a Master Student at Faculty of Economics and Business, Universitas Gadjah Mada, Indonesia. E-mail: dhiah.basuki@gmail.com

${ }^{2}$ Rahmi Budhy Fatmasari is a Master Student at Faculty of Economics and Business, Universitas Gadjah Mada, Indonesia. email: frahmibudhy@gmail.com
} 


\section{Peran Kerangka Kerja Kelembagaan dan Teknologi Terhadap Ketahanan Pangan Jangka Panjang di Indonesia: Pendekatan Autoregressive Distributed Lag}

\section{Rodhiah Umaroh dan Rahmi Budhy Fatmasari}

\section{Pendahuluan}

1.1. Latar belakang

Pangan merupakan soal hidup-matinya suatu bangsa (Soekarno, 1952). Ketahanan pangan menjadi bagian yang sangat penting dari ketahanan nasional, karena kekurangan pangan dianggap sebagai suatu proses sebab akibat adanya permasalahan kemiskinan. Pemenuhan kebutuhan pangan menjadi hal yang sangat penting dan strategis dalam mempertahankan kedaulatan negara, dengan tidak bergantung pada impor pangan dari negara maju. Ketergantungan suatu negara akan impor pangan hanya akan mengakibatkan pengambilan keputusan atas segala aspek kehidupan menjadi tidak bebas atau tidak merdeka, dan karenanya negara menjadi tidak berdaulat secara penuh (Arifin, 2004).

Saat ini sektor pertanian di Indonesia dapat dikatakan sebagai roda penggerak perekonomian nasional. Selain menghasilkan bahan pangan yang dapat memenuhi kebutuhan masyarakat, sektor pertanian juga menjadi prioritas pemerintah untuk ditingkatkan nilai produktivitasnya. Apabila diukur dari sisi produksi, saat ini sektor pertanian Indonesia merupakan sektor kedua dengan kontribusi tertinggi terhadap pertumbuhan ekonomi nasional. Guna mencukupi kebutuhan pangan, hal yang perlu diperhatikan oleh suatu negara adalah memastikan ketersediaan pangan, menyediakan kemudahan akses pangan dan menyediakan bantuan bagi rumah tangga atau keluarga untuk dapat memenuhi kebutuhan makanan pokoknya. Selain hal tersebut, investasi di bidang teknologi pertanian juga memiliki peranan sangat penting dalam memastikan ketersediaan pangan secara global dan juga berperan sebagai sumber utama dalam pendapatan yang akan meningkatkan kemampuan daya beli rumah tangga dalam mengonsumsi makanan dengan nilai gizi yang tinggi (Osabohien dkk, 2013).

Sesuai dengan target Pemerintah Indonesia pada tahun 2045 yang ingin mewujudkan Indonesia sebagai lumbung pangan dunia, swasembada pangan perlu diciptakan terlebih dahulu agar kebutuhan pangan rakyat Indonesia tercukupi yang selanjutnya perwujudan Indonesia sebagai lumbung padi dunia dapat dilaksanakan. Grabowski dan Self (2007) menjelaskan 
pentingnya penggunaan teknologi pertanian modern dalam mendorong pertumbuhan ekonomi dan pembangunan. Dalam hal ini teknologi pertanian yang dimaksud adalah pupuk, traktor dan sumber daya manusia. Sementara itu kualitas kelembagaan suatu negara merupakan faktor penting dalam pertumbuhan jangka panjang. Kelembagaan merupakan bagian dari modal sosial (social capita) yang merupakan jalinan ikatan-ikatan budaya, pemerintahan, dan perilaku sosial yang membuat fungsi dan tatanan sebuah masyarakat lebih dari sekedar jumlah individunya.

Meskipun saat ini sektor industri pengolahan mendominasi dalam memberikan kontribusi tertinggi terhadap perekonomian di Indonesia, namun jati diri Indonesia sebagai negara agraris harus tetap ada. Persoalan pangan yang menjadi penentu hidup-matinya suatu bangsa memberikan gambaran bahwa ketiadaan pangan yang mengakibatkan bencana kelaparan sudah mewabah ke berbagai negara di penjuru belahan dunia. Demi mewujudkan kesejahteraan rakyat Indonesia, pemerintah telah menebarkan visi Indonesia sebagai Lumbung Pangan Dunia di tahun 2045. Dengan upaya meningkatkan mengurangi impor dan meningkatkan swasembada padi, jagung, bawang merah, bawang putih, cabai, kedelai, daging sapi, gula konsumsi dan gula industri. Berdasarkan pemaparan tersebut, penelitian ini bertujuan untuk menganalisis pengaruh kelembagaan dan teknologi pertanian terhadap kemandirian pangan Indonesia dalam jangka pendek dan jangka panjang.

\subsection{Pertanyaan Penelitian}

Adapun pertanyaan dalam penelitian ini adalah sebagai berikut:

1. Bagaimana peran penggunaan teknologi pertanian terhadap nilai indeks produksi pangan di Indonesia pada jangka pendek dan jangka panjang?

2. Bagaimana peran kerangka kelembagaan terhadap nilai indeks produksi pangan di Indonesia pada jangka pendek dan jangka panjang?

\subsection{Kerangka Berpikir}

Kerangka kerja kelembagaan (institutional framework) dapat dijadikan sebagai aturan main atau alat pengatur kebijakan. Kerangka kerja kelembagaan dalam konteks ketahanan pangan meliputi distribusi dan akses makanan oleh individu, rumah tangga, komunitas dan nasional (Osabohien et al., 2018). Pada penelitian ini, konsep utamanya adalah berdasarkan fakta bahwa sebuah lembaga membutuhkan kerangka kerja supaya dapat berfungsi secara efektif. Dengan demikian, sebuah lembaga sangat penting untuk pencapaian ketahanan pangan (Blondeau, 2014). Di Indonesia, kebijakan mengenai pertanian dan ketahanan pangan pertama kali diluncurkan setelah kemerdekaan tahun 1948 oleh Kementerian Pertanian (Kasimo). Rencana tersebut diarahkan untuk mencapai swasembada pangan dan menetapkan panduan praktis dalam mencapai tujuan tersebut. Program tersebut kemudian dilanjutkan oleh Presiden Soeharto melalui program REPELITA dan mulai 
memperkenalkan Badan Urusan Logistik atau BULOG. Meskipun terjadi pergantian pemerintahan, tujuan kebijakan pemerintah Indonesia pada sektor pertanian masih tetap sama yaitu mencapai swasembada pangan (Limenta \& Chandra, 2017). Namun, kebijakan tersebut terkadang hanya menjadi sekadar kebijakan yang tidak efisien dan kurangnya perencanaan karena pada praktiknya untuk mencapai swasembada pangan pemerintah juga tetap mengimpor makanan dalam jumlah besar sehingga produktivitas petani dalam negeri tetap tidak meningkat.

Dalam mengukur kinerja lembaga di pemerintahan, beberapa peneliti menggunakan indikator political rights dan civil liberties (J. Fedderke \& Garlick, 2011; J. W. Fedderke, De Kadt, \& Luiz, 2001; Osabohien et al., 2018). Secara singkat, Political rights dan civil liberties mengukur keadaan kebebasan yang luas di suatu negara yang sangat penting bagi ketahanan pangan. Indikator political rights dan civil liberties dihimpun oleh lembaga Freedom House yang memiliki nilai dari 1 sampai 7 . Nilai 1 menunjukkan kebebasan tertinggi dan 7 adalah kebebasan terendah.

Gambar 1. Tipologi ketahanan pangan (interaksi antara teknologi dan lembaga pemerintahan)

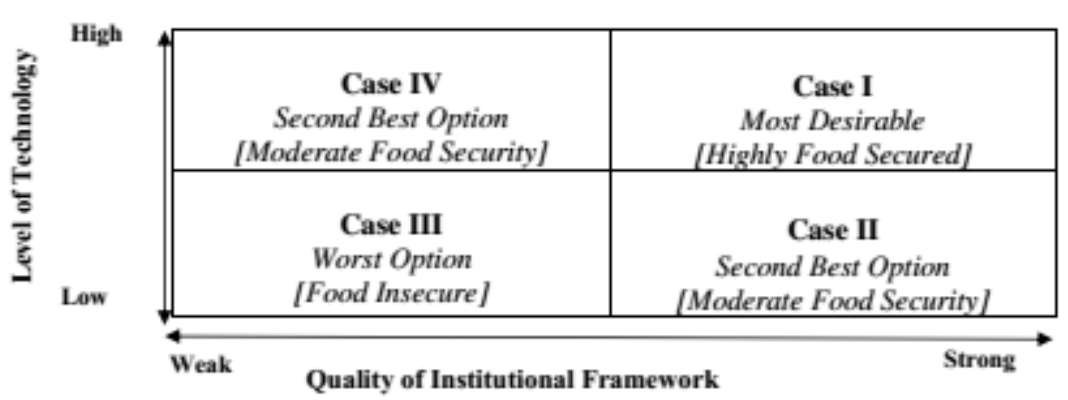

Sumber: (Osabohien et al., 2018)

Hal yang penting dan sangat perlu menjadi perhatian dalam ketahanan pangan dan sektor pertanian adalah penggunaan teknologi. Teknologi yang dibutuhkan untuk ketahanan pangan akan berbeda-beda pada setiap negara tergantung pada lingkungan, infrastruktur, iklim, budaya, pendidikan, kondisi ekonomi dan pemerintahan. Di negara berkembang, teknologi yang digunakan termasuk persiapan lahan, pengelolaan tanah dan air, produksi benih, manajemen hama dan penyakit, pengelolaan pertanian dan praktik pasca panen seperti penyimpanan, pengolahan, pengemasan, pemasaran dan distribusi (Andrade, 2016). Oleh karena itu, ketahanan pangan di suatu negara juga bergantung dari penggunaan teknologi.

Gambar 1 menunjukkan interaksi antara penggunaan teknologi dan kualitas lembaga pemerintahan. Pada gambar tersebut, Case I menunjukkan penggunaan teknologi yang tinggi digabungkan dengan kerangka kerja kelembagaan yang kuat. Ini adalah kuadran yang paling diinginkan. Namun 
untuk mencapai kuadran tersebut mungkin terdapat beberapa kendala mulai dari sumber daya (manusia dan material) dan kurangnya perlindungan sosial yang tidak memadai di sektor pertanian. Ketika terjadi harmonisasi antara teknologi dan kerangka kerja kelembagaan yang baik maka asumsinya akan terjadi ketahanan pangan terutama dari sektor pertanian yang baik tidak hanya dalam jangka pendek maupun juga dalam jangka panjang. Oleh karena itulah penelitian ini berusaha untuk mengkaji peran kerangka kerja kelembagaan dan teknologi terhadap ketahanan pangan dalam jangka panjang sesuai dengan cita-cita bangsa Indonesia yang sudah dirancang oleh para pendiri bangsa.

II. Tinjauan Literatur

Ketahanan pangan merupakan istilah yang digunakan untuk mendeskripsikan apakah individu telah memiliki akses pada kualitas dan kuantitas makanan yang memadai. Komponen ketahanan pangan meliputi: (1) ketersediaan makanan atau jumlah makanan yang benar-benar ada (produksi lokal atau sumber lainnya); (2) orang-orang dapat mengakses makanan (kapasitas untuk memproduksi/membeli/ memperoleh makanan) dengan stabil dari waktu ke waktu secara fisik, ekonomi dan sosial; dan (3) ketersediaan makanan yang berkualitas dan cukup gizi. Melihat dari definisinya, ketahanan sangat penting bagi semua negara di dunia.

Penyebab terjadinya kerawanan pangan (food insecurity) dapat disebabkan oleh banyak faktor seperti faktor ketidakstabilan politik, terjadinya perang, penurunan perdagangan akibat kerusakan lingkungan, kemiskinan, pertumbuhan populasi yang terlalu cepat, ketimpangan gender, pendidikan yang tidak memadai dan kesehatan yang buruk (Smitha, Obeidb, \& Jensenb, 2000). Menurut Osabohien, Osabuohien, \& Urhie (2018), masalah ketahanan pangan terjadi bukan karena masalah kelangkaan pangan namun masalah tidak memadainya akses orang-orang terhadap makanan yang dibutuhkan. Oleh karena itu, masalah ketahanan pangan dapat terjadi dimanapun baik di negara miskin, negara berkembang bahkan negara maju.

Status ketahanan pangan berbeda-beda pada masing-masing negara. Dalam konteks di negara berkembang, umumnya ketahanan pangan masih terjadi namun tidak cukup parah atau dengan kata lain masih dalam fase medium (Sethi, 2011). Beberapa penelitian mengenai ketahanan pangan juga telah dilakukan di Indonesia. Meskipun ketahanan pangan di Indonesia sudah menunjukkan arah positif dari tahun ke tahun namun Indonesia masih rentan dalam masalah ketahanan pangan. Setidaknya terdapat 32 persen rumah tangga yang masih mengonsumsi di bawah jumlah yang direkomendasikan (Pangaribowo \& Daniel, 2011). Penyebab terjadinya masalah ketahanan pangan yang rentan di Indonesia pun beragam seperti dari aspek sosial, ekonomi, lingkungan, politik dan lainnya. Hakim \& Herdiansah (2017) menyebutkan bahwa meskipun curah hujan di Indonesia cukup tinggi namun suhu dan kondisi tanah juga perlu diperhatikan untuk mendukung hasil produksi pertanian, akan tetapi 
keadaan tersebut bersifat tidak pasti dan tidak stabil karena selalu berubah sesuai dengan keadaan atmosfer secara terpadu. Selanjutnya, Mujahid \& Kalkuhl (2015) dalam penelitiannya menunjukkan bahwa dalam kurun waktu 10 tahun dari 2004-2014 telah terjadi fluktuasi harga makanan yang diiringi dengan risiko kerawanan pangan dan nutrisi yang cukup tinggi. Sedangkan Suryana (2014) berpendapat bahwa aspek politik seringkali menjadi faktor dominan dalam lambatnya penanganan masalah ketahanan pangan di Indonesia terutama saat menyangkut masalah pengambilan keputusan.

\section{Metodologi}

\subsection{Data}

Pemodelan ketahanan pangan dalam penelitian ini menggunakan data time series tahun 1978-2014 dengan total sebanyak 35 observasi pada setiap variabel. Variabel yang digunakan adalah indeks produksi makanan (food production index) yang merupakan proksi dari ketahanan pangan sebagai variabel dependen. Variabel independen dalam penelitian ini adalah jumlah penggunaan mesin traktor dan ketersediaan listrik sebagai proksi dari penggunaan teknologi pada sektor pertanian. Selanjutnya, untuk mengontrol peran kelembagaan pemerintah digunakan variabel political rights dan civil liberties. Variabel lainnya ditambahkan karena diyakini turut mempengaruhi indeks produksi pangan yaitu Gross Domestic Produc (GDP) per kapita. Data yang digunakan dalam penelitian ini diperoleh dari Worldbank Development Index (WDI) dan Freedom House. Data yang tidak tersedia dalam bentuk persen akan ditransformasikan ke dalam bentuk logaritma.

\subsection{Spesifikasi model}

Penelitian ini menspesifikasikkan model di bawah ini untuk mengestimasi peran kerangka kerja kelembagaan dan teknologi terhadap ketahanan pangan di Indonesia. Model estimasinya didefinisikan sebagai berikut:

$$
\begin{aligned}
\text { food }_{t}=\alpha_{0}+\beta_{1} \ln (\text { land })_{t} & +\gamma_{2} \ln \left(\text { machine }_{t}+\partial_{3} \ln (\text { electr })_{t}\right. \\
& +\delta_{4} \text { civil }_{t}+\theta_{5} \text { pol_rights }_{t}+\vartheta_{6} \ln (G D P)_{t}+\varepsilon_{t}
\end{aligned}
$$

Dimana, $\operatorname{food}_{t}$ adalah ketahanan pangan (indeks produksi makanan), land $_{t}$ adalah ketersediaan lahan, machine $t$ merupakan mesin pertanian, electr $_{t}$ adalah ketersediaan listrik, civil $_{t}$ adalah indeks civil liberties, pol_rights $t_{t}$ merupakan indeks political rights, $G D P_{t}$ adalah Gross Domestic Product (GDP) per Kapita dan $\varepsilon_{t}$ adalah error term. Ln merepresentasikan logaritma natural dan $\alpha_{0}, \beta_{1}, \gamma_{2}, \partial_{3}, \delta_{4}, \theta_{5}$, dan $\vartheta_{6}$ adalah parameter dugaan.

Lebih lanjut, ketika melakukan estimasi pada data time series, diasumsikan bahwa seluruh variabel harus bersifat stasioner (Ericsson \& Mackinnon, 1999). Data yang tidak stasioner akan berdampak pada interpretasi hasil karena dapat memiliki arti yang berbeda pada setiap titik tertentu atau dengan kata lain koefisien estimasi akan menjadi bias (Nelson \& Plosser, 1982). 
Oleh karena itu, sangat penting untuk melakukan uji stasioneritas guna menghilangkan isu spurious regression. Penelitian ini menggunakan uji stasioneritas Augmented Dicky Fuller (ADF) dan Phillips-Perron.

\subsection{Model Estimasi}

Analisis hubungan jangka panjang dan jangka pendek antara variabel dependen dengan variabel independen dalam penelitian ini diestimasi dengan menggunakan pendekatan Autoregressive Distributed Lag (ARDL) uji Bound yang dikembangkan oleh Pesaran \& Shin (1997). Berbeda dengan pendekatan lainnya yang mengharuskan seluruh variabel stasioner pada order yang sama, pendekatan ARDL mengizinkan untuk mengaplikasikan kombinasi lag variabel dependen dan independen yang terintegrasi pada order $0 \mathrm{I}(0)$ dan order pertama I(1). Persamaan ARDL adalah sebagai berikut:

$$
\begin{aligned}
\text { food }_{t}=\alpha_{0}+\beta_{1} & \ln (\text { land })_{t-1}+\gamma_{2} \ln (\text { machine })_{t-1}+\partial_{3} \ln (\text { electr })_{t-1} \\
& +\delta_{4} \text { civil }_{t-1}+\theta_{5} \text { pol_rigths } s_{t-1}+\vartheta_{6} \ln (\text { GDP })_{t-1} \\
& +\sum_{i=1}^{l} \beta_{7} \Delta \ln (\text { land })_{t-1}+\sum_{i=0}^{m} \gamma_{8} \Delta \ln (\text { machine })_{t-1} \\
& +\sum_{i=0}^{n} \partial_{9} \Delta \ln (\text { electr })_{t-1}+\sum_{i=0}^{c} \delta_{10} \Delta \text { civil }_{t-1} \\
& +\sum_{i=0}^{p} \theta_{11} \Delta \text { pol_rigth } s_{t-1}+\sum_{i=0}^{q} \vartheta_{12} \Delta \ln (G D P)_{t-1}+\varepsilon_{t}(2)
\end{aligned}
$$

Dimana I, m, n, o, p, q adalah lag optimal, $\beta_{1}, \gamma_{2} \partial_{3}, \delta_{4}, \theta_{5}$, dan $\vartheta_{6}$ merupakan koefisien jangka panjang dan $\beta_{7}, \gamma_{8} \partial_{9}, \delta_{10}, \theta_{11}$, dan $\vartheta_{12}$ adalah koefisien jangka pendek dalam model.

\section{Hasil Penelitian}

Sebelum mengaplikasikan pendekatan kointegrasi ARDL, uji unit root diaplikasikan untuk mengetahui apakah variabel dalam penelitian stasioner atau

\begin{tabular}{|c|c|c|c|c|}
\hline \multirow[t]{2}{*}{ Variabel } & \multicolumn{2}{|c|}{$\begin{array}{l}\text { Uji statistik Augmented Dicky } \\
\text { Fuller }\end{array}$} & \multicolumn{2}{|c|}{ Uji statistik Phillips-Perron } \\
\hline & Intercept & Intercept \& trend & Intercept & $\begin{array}{l}\text { Intercept \& } \\
\text { trend }\end{array}$ \\
\hline Food & 2,051 & -0.507 & 2,182 & $-0,577$ \\
\hline Food (-1) & $-5,501^{\star \star \star}$ & $-6,145^{* * \star}$ & $-5,615^{\star * *}$ & $-6,141^{* * *}$ \\
\hline Land & 0,070 & $-2,103$ & $-0,005$ & $-2,103$ \\
\hline Land (-1) & $-4,962^{* * *}$ & $-4,918^{* * *}$ & $-4,919 * * *$ & $-4,867^{\star \star \star}$ \\
\hline Machine & $-5,571^{\star \star \star}$ & $-5,863^{\star \star *}$ & $-5,595^{\star \star *}$ & 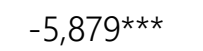 \\
\hline
\end{tabular}
tidak. Hasil Uji unit root pada Tabel 1 menunjukkan bahwa seluruh variabel stasioner pada orde 1 sedangkan variabel penggunaan mesin teknologi dan ketersediaan listrik stasioner pada tingkat level.

Tabel 1. Uji unit root (Stasioneritas data) 


\begin{tabular}{|c|c|c|c|c|}
\hline Electr & $-3.371^{\star \star}$ & $-3,560^{\star *}$ & $-3,578^{\star * *}$ & $-3,640^{* *}$ \\
\hline Civil & $-1,256$ & $-2,143$ & $-1,256$ & $-2,143$ \\
\hline Civil(-1) & $-5,768^{\star \star \star}$ & 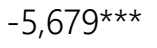 & $-5,768^{\star \star \star}$ & $-5,680^{\star \star \star}$ \\
\hline Pol_rights & $-1,062$ & $-2,019$ & $-0,783$ & $-1,695$ \\
\hline $\begin{array}{l}\text { Pol_rights(- } \\
\text { 1) }\end{array}$ & $-3,635^{\star \star \star}$ & $-3,628^{\star \star}$ & $-3,633^{\star \star *}$ & $-3,628^{* *}$ \\
\hline$G d p$ & 1,602 & $-1,357$ & 1,602 & $-0,876$ \\
\hline$G d p(-1)$ & $-4,054^{\star \star \star}$ & $-4,296^{\star \star \star}$ & $\begin{array}{c}- \\
4,054^{\star \star \star}\end{array}$ & $-4,270^{\star}$ \\
\hline
\end{tabular}

Ket: ${ }^{* \star}$ dan ${ }^{* \star *}$ menunjukkan taraf signifikansi $5 \%$ dan $10 \%$

Prosedur selanjutnya pada pendekatan ARDL adalah dibutuhkannya panjang Lag yang sesuai untuk menghilangkan isu serial correlation. Hasil pemilihan panjang lag optimum dan hasil Uji diagnostik ditampilkan pada Tabel 2 yang menunjukkan bahwa data variabel dalam model sudah memenuhi syarat estimasi pendekatan ARDL. Nilai F-statistik melebihi nilai upper bound dan lower bound yang mengkonfirmasi adanya hubungan kointegrasi antar variabel di dalam model.

Tabel 2. Seleksi model dan hasil kointegrasi

\begin{tabular}{|c|c|c|c|c|c|c|c|}
\hline Variabel & Food & Land & Machine & Electr & Civil & Pol_rights & $G d p$ \\
\hline $\begin{array}{l}\text { Lag optimum } \\
\text { terpilih }\end{array}$ & 1 & 2 & 2 & 0 & 1 & 0 & 0 \\
\hline F-statistic & 10.172 & & & & & & \\
\hline $\begin{array}{l}\text { Nilai kritis (5\%) } \\
\text { Upper bound } \\
\text { Lower bound }\end{array}$ & $\begin{array}{l}3,25 \\
2,97\end{array}$ & & & & & & \\
\hline $\begin{array}{l}\text { Diagnostic } \\
\text { check }\end{array}$ & & & & & & & \\
\hline $\begin{array}{l}\text { Residual } \\
\text { Stasionerity (1\%) }\end{array}$ & \multicolumn{2}{|c|}{$-5,892(0,000)$} & & & & & \\
\hline LM test & 0,0878 & & & & & & \\
\hline $\begin{array}{l}\text { Breusch-Pagan- } \\
\text { Godfrey }\end{array}$ & 0.9935 & & & & & & \\
\hline Ramsey RESET & 0,7041 & & & & & & \\
\hline
\end{tabular}

Selanjutnya uji stabilitas digunakan untuk menginvestigasi stabilitas parameter dalam jangka panjang dan jangka pendek. Hasil uji stabilitas ditunjukkan oleh uji CUSUM dan CUSUMSQ. Dari gambar 2 dapat dilihat bahwa garis biru selalu berada di antara garis merah yang mengindikasikan bahwa parameter dalam model estimasi stabil dari waktu ke waktu. 
Gambar 2. CUSUM dan CUSUMSQ
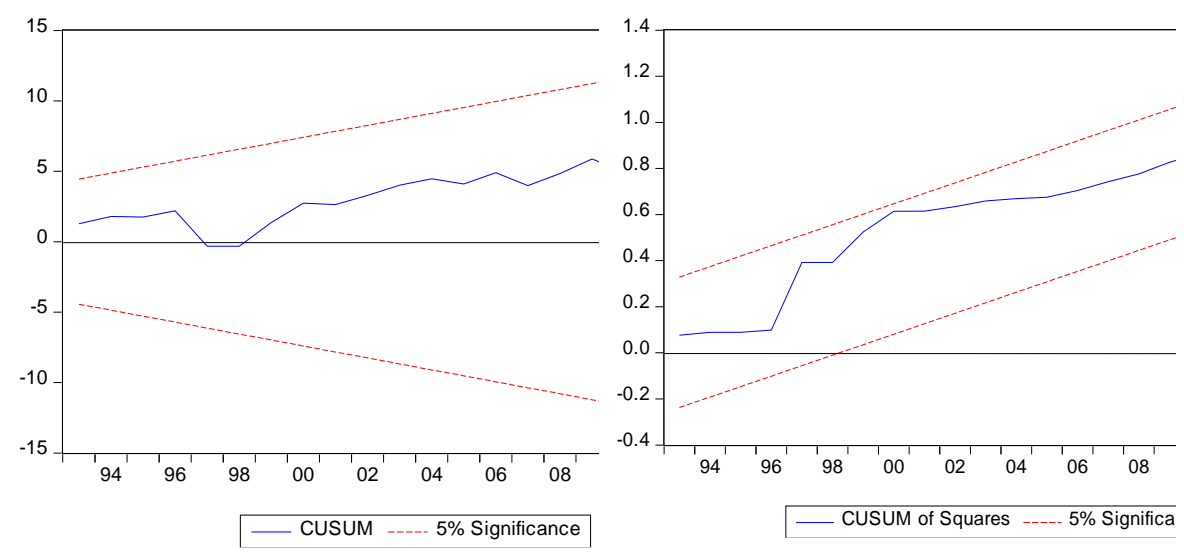

4.1. Hasil Estimasi Jangka Pendek ARDL

Hasil estimasi jangka pendek ARDL ditunjukkan melalui tabel berikut: Tabel 3. Hasil Estimasi Jangka Pendek

\begin{tabular}{|c|c|c|c|}
\hline \multicolumn{4}{|c|}{ Variabel dependen $=\Delta$ food $_{t}$} \\
\hline Variabel & Koef & Std. Err & t-stat \\
\hline$\Delta \ln (\text { land })_{t}$ & 17,811 & 10,837 & 1.643 \\
\hline$\Delta \ln (\text { land })_{t-1}$ & $-48,905$ & 12,461 & $-3,924^{* * *}$ \\
\hline$\Delta \ln (\text { machine })_{t}$ & 2.174 & 0.756 & $2,873^{* * *}$ \\
\hline$\Delta \ln (\operatorname{machine})_{t-1}$ & 1.559 & 0.764 & $2,039 *$ \\
\hline$\Delta e l e c t r_{t}$ & 1.966 & 1.055 & $1.863^{*}$ \\
\hline civil $_{t}$ & 2,397 & 1.401 & 1,710 \\
\hline pol_rights $t_{t}$ & $-0,989$ & 0,640 & $-1,545$ \\
\hline $\ln (G D P)_{t}$ & 11,730 & 10,131 & 1.157 \\
\hline$E C T_{t-1}$ & $-0,247$ & 0.023 & $-10.35^{\star * *}$ \\
\hline
\end{tabular}

Ket: ${ }^{*}, * *, \& * *$ menunjukkan taraf signifikansi 10\%, 5\% \& 1\% Sumber: output Eviews 10, diolah

4.2. Hasil Estimasi Jangka Panjang ARDL

Hasil estimasi jangka pendek ARDL ditunjukkan melalui tabel berikut:

Tabel 4. Hasil Estimasi Jangka Panjang

\begin{tabular}{|clll|}
\hline \multicolumn{4}{|c|}{ Variabel dependen $=\Delta$ food $_{t}$} \\
\hline Variabel & Koef. & Std. Err & t-stat \\
$\ln (\text { land })_{t}$ & 165,590 & 65,839 & $2,515^{\star *}$ \\
$\ln \left({\text { machine })_{t}}\right.$ & $-9,368$ & 8,477 & $-1,105$ \\
electr $_{t}$ & $-0,545$ & 9,758 & $-0,055$ \\
civil $_{t}$ & 9,700 & 3,872 & $2,502^{\star *}$ \\
pol_rights $_{t}$ & $-4,002$ & 1,985 & $-2,015^{\star}$ \\
$\ln (G D P)_{t}$ & 47,460 & 21,372 & $2,220^{\star *}$
\end{tabular}




$$
\text { C } \quad-2375,34 \quad 723,564-3,28 * *
$$

Ket: ${ }^{*}, * *, \& * * *$ menunjukkan taraf signifikansi $10 \%, 5 \%$ \& $1 \%$ Sumber: output Eviews 10, diolah

\section{Analisis dan Diskusi}

\subsection{Hasil Estimasi Jangka Pendek ARDL}

Dari hasil estimasi jangka pendek ARDL, terlihat bahwa variabel luas lahan (/and) dalam jangka pendek memiliki nilai koefisien terbesar, artinya faktor ketersediaan lahan merupakan faktor dominan yang mempengaruhi nilai produksi pangan. Pertambahan luas lahan sebesar 1 persen akan meningkatkan produksi pangan Indonesia sebesar 17,8 persen. Namun untuk variabel luas lahan di periode sebelumnya justru memiliki hubungan negatif dan signifikan terhadap nilai produksi pangan dalam jangka pendek. Hal ini dapat disebabkan oleh alih fungsi lahan pertanian, dimana jumlah penduduk Indonesia yang semakin bertambah akan berimplikasi terhadap tingginya permintaan lahan hunian/pemukiman. Oleh karena itu, jumlah lahan yang tersedia di periode sebelumnya tidak berkontribusi terhadap peningkatan nilai produksi pangan di Indonesia dalam jangka pendek.

Terkait dengan faktor teknologi pertanian, variabel penggunaan mesin pada periode saat ini dan sebelumnya pada jangka pendek, memiliki peranan terhadap peningkatan nilai produksi tanaman pangan. Dimana apabila penggunaan traktor pada periode saat ini dan periode sebelumnya meningkat sebesar satu persen, maka akan meningkatkan nilai produksi pangan berturutturut sebesar 2,174 persen dan 1,559 persen.

Adanya hubungan positif dalam jangka pendek antara penggunaan teknologi (traktor) terhadap nilai produksi pangan, didukung oleh Las (2002) yang menjelaskan peranan peningkatan produktivitas (teknologi) dalam peningkatan produksi padi mencapai 56,10\%, per luas areal. Rendahnya pemakaian traktor mencerminkan mekanisasi pertanian yang masih rendah. Hilangnya hasil dan keuntungan dari sektor pertanian masih besar dan penanganan pasca panen tergolong kurang sehingga produk yang dihasilkan mutunya kurang baik.

Selanjutnya untuk variabel ketersediaan listrik dalam jangka pendek memiliki hubungan positif terhadap nilai produksi pangan Indonesia. Dimana setiap peningkatan ketersediaan listrik sebesar satu persen, maka akan meningkatkan nilai produksi pangan sebesar 1,966 persen. Faktor kelembagaan yang terdiri dari variabel civil liberties dan political rights dalam jangka pendek memiliki nilai koefisien sebesar 2,397 dan -0,989 yang tidak signifikan.

Faktor pertumbuhan ekonomi dalam jangka pendek memiliki peranan yang relatif besar, dimana peningkatannya sebesar 1 persen akan meningkatkan nilai produksi tanaman pangan sebesar 17,3 persen. Rusdiana dan Mesya (2017) menjelaskan bahwa pertumbuhan ekonomi di Indonesia dapat berpengaruh nyata terhadap kebutuhan pangan. Hal ini didorong oleh peningkatan 
permintaan pangan akibat dari meningkatnya pendapatan masyarakat. Indonesia memiliki potensi sumber daya yang beragam dan memiliki peluang untuk mencapai kemandirian pangan yang berkelanjutan. Selain penjelasan tersebut, pertumbuhan ekonomi yang meningkat menandakan adanya stabilitas politik dan ekonomi secara tidak langsung akan turut mempengaruhi peningkatan produksi pangan di Indonesia melalui segi kebijakan.

\subsection{Hasil Estimasi Jangka Panjang ARDL}

Dari hasil estimasi jangka panjang ARDL, ditunjukkan bahwa variabel ketersediaan lahan dalam jangka panjang memiliki nilai koefisien terbesar, artinya faktor ketersediaan lahan merupakan faktor yang paling berkontribusi dalam mempengaruhi nilai produksi pangan Indonesia. Secara statistik ketersediaan lahan signifikan mempengaruhi nilai produksi pangan, dimana bertambahnya ketersediaan lahan sebesar satu persen maka akan meningkatkan nilai produksi pangan sebesar 165,590 persen. Purnomo (2016) menyatakan bahwa guna memenuhi kebutuhan pangan yang selalu meningkat dan agar ketergantungan pada impor komoditas pangan menurun atau bila mungkin dihentikan, maka diperlukan upaya peningkatan potensi produksi tanaman baik secara intrinsik maupun ekstrinsik, perluasan lahan pertanian atau luas panen melalui peningkatan intensitas pertanaman, pencegahan kehilangan hasil pra panen dan pascapanen dan ketergantungan pangan pada satu komoditas harus dihindari dengan memasyarakatkan penganekaragaman pangan.

Penggunaan teknologi pertanian (traktor) dalam jangka panjang justru memiliki hubungan negatif dan tidak mempengaruhi nilai produksi pangan secara signifikan. Selain itu, ketersediaan listrik dalam jangka panjang juga memiliki hubungan negatif dan tidak berpengaruh terhadap produksi pangan. Faktor kelembagaan yang ditinjau dari civil liberties dan political rights dalam jangka panjang memiliki pengaruh yang berbeda untuk tiap nilai produksi pangan. Variabel civil liberties memiliki pengaruh yang positif signifikan dengan nilai koefisien 9,7 yang berarti bahwa setiap kenaikan hak dan perlindungan masyarakat atas tindakan pemerintah meningkat sebesar satu persen maka nilai produksi pangan akan meningkat sebesar 9,7 persen. Sementara political rights memiliki nilai koefisien sebesar -4,002 yang berarti bahwa setiap peningkatan political rights sebesar satu persen akan menurunkan nilai produksi pangan. Kedua faktor kelembagaan tersebut memiliki konsekuensi yang berbeda terhadap nilai produksi pangan di Indonesia dalam jangka panjang.

Osabohien, dkk (2016) menjelaskan bahwa kuatnya kelembagaan akan mendorong peningkatan ketahanan pangan melalui kebijakan yang efektif dan efisien, namun hal tersebut tidak berlaku bagi kondisi pertanian Indonesia dalam jangka panjang, terutama faktor political rights. Semakin tingginya hak dan partisipasi masyarakat dalam bidang politik dan pemerintah dapat dimanfaatkan oleh kepentingan beberapa oknum tertentu, sehingga kebijakan 
yang dikeluarkan di sektor pertanian cenderung hanya memberikan keuntungan bagi oknum tertentu. Maka dari itu untuk mencegah adanya tindakan moral hazard dari pemberlakuan sebuah kebijakan dalam jangka panjang, maka kebijakan pertanian yang akan diterapkan harus tepat sasaran dan tepat guna.

Selanjutnya faktor ekonomi yakni variabel pertumbuhan ekonomi (InGDP) dalam jangka panjang memiliki hubungan positif dan signifikan mempengaruhi nilai produksi pangan Indonesia. Dimana nilai koefisiennya yang bernilai 47,460 memiliki arti bahwa setiap kenaikan pertumbuhan ekonomi sebesar satu persen, maka nilai produksi pangan akan meningkat sebesar 47,460 persen. Laporan FAO (2018) menyatakan bahwa dalam dekade terakhir perekonomian telah tumbuh di semua wilayah dan memberikan bukti bahwa pertumbuhan tersebut dapat menjadi pendorong yang kuat untuk peningkatan ketahanan pangan dan menjangkau petani kecil dan perempuan.

VI. Kesimpulan dan Rekomendasi

6.1. Kesimpulan

a. Pengaruh jangka pendek dari penggunaan traktor di periode saat ini dan sebelumnya berpengaruh positif dan signifikan terhadap nilai produksi pangan. Sementara kelembagaan tidak signifikan mempengaruhi peningkatan produksi pangan.

b. Pengaruh jangka panjang dari penggunaan traktor tidak signifikan terhadap nilai produksi pangan. Faktor kelembagaan, seperti civil liberties memiliki hubungan positif dan signifikan dalam mempengaruhi nilai produksi pangan. Sementara political rights memiliki hubungan negatif dan signifikan terhadap nilai produksi pangan.

6.2. Rekomendasi

a. Penelitian ini dibuat dalam lingkup nasional, pada penelitian selanjutnya supaya dapat dibuat pada lingkup per daerah provinsi supaya hasilnya lebih detail.

b. Indikator ketahanan pangan dalam penelitian ini hanya menggunakan indeks produksi makanan, pada penelitian selanjutnya dapat menambahkan indikator lainnya.

c. Penggunaan teknologi dalam penelitian ini hanya menggunakan jumlah traktor, akan lebih baik jika pada penelitian selanjutnya menambahkan indikator lainnya supaya dapat menghasilkan analisis lebih detail.

VII. Daftar Pustaka

Andrade, M. (2016). The Role of Technology in Achieving Global Food Security. Retrieved from

https://www.worldfoodprize.org/index.cfm/88533/18104/the_role_of_tec 
hnology_in_achieving_global_food_security

Arifin, Bustanul. (2005). Kebijakan Kelembagaan Pangan. LP2ES. Jakarta

Blondeau, S. (2014). Institutional Framework for the Right To Adequate Food Thematic Study 2, 14. Retrieved from http://www.fao.org/3/a-i3891e.pdf

Dev, S. M., \& Sharma, A. N. (2010). Food Security in India: Performance, Challenges and Policies. Oxfam India Working Papers Series (OIWPS)- VII, (September), 1-40.

Ericsson, N. R., \& Mackinnon, J. G. (1999). Distributions of Error Correction Tests for Cointgration. International Flnance Discussion Papers, No. 655, 1-48.

Fedderke, J., \& Garlick, J. (2011). Measuring Institutions: Indicators of Political and Property Rights in Malawi. https://doi.org/10.1007/s11205-011-9819-4

Fedderke, J. W., De Kadt, R. H. J., \& Luiz, J. M. (2001). Indicators of political liberty, property rights and political instability in South Africa: 1935-97. International Review of Law and Economics, 21(1), 103-134. https://doi.org/10.1016/S0144-8188(00)00051-X

Food and Agrciulture Irganization. 2018. The State of Food Security and Nutrition in The World.

Grabowski, R. dan Self, S. 2007. Economic Development and The Role of Agricultural Technology. Agricultural Economics. 36(3), 395-404.

Hakim, D. L., \& Herdiansah, D. (2017). Food Security Production Challenges in Indonesia as Impact of Global Climate Change. International Journal of Environmental \& Agriculture Research, 3(7), 26-33.

Limenta, M. E., \& Chandra, S. (2017). Indonesian Food Security Policy. Indonesia Law Review, 7(2), 245-265. https://doi.org/10.15742/ilrev.v7n2.198

Mujahid, I., \& Kalkuhl, M. (2015). Food Price Crisis in Indonesia : Alert from the Key Markets Food Price Crisis in Indonesia : Alert from the Key Markets. In Applied Economics Association and Western Agricultural Economics Association Annual Meeting. San Fransisco.

Nelson, C. R., \& Plosser, C. I. (1982). Trends and random walks in macroeconomic time series: some evidence and implications. Journal of Monetary Economu, 10(1), 39-62.

Olielo, T. (2013). Food security problems in various income groups of Kenya. African Journal of Food, Agriculture, Nutrition and Development, 13(4), 113. https://doi.org/10.1002/ejoc.201000164

Osabohien, R., Osabuohien, E., \& Urhie, E. (2018). Food Security, Institutional Framework and Technology: Examining the Nexus in Nigeria Using ARDL Approach. Current Nutrition \& Food Science, 14(2), 154-163. https://doi.org/10.2174/1573401313666170525133853

Pangaribowo, E. H., \& Daniel, T. (2011). Food demand analysis of Indonesian households with particular attention to the poorest. ZEF-Discussion Papers on Development Policy, (151).

Pesaran, H., \& Shin, Y. (1997). An autoregressive distributed lag modelling approach to cointegration analysis. Econometrics and Economic Theory 
in the 20th Century: The Ragnar Frisch Centennial Symposium., 1-31. https://doi.org/10.1017/CCOL521633230

Rusdiana, S. dan Mesya, A. 2017. Pertumbuhan Ekonomi dan Kebutuhan Pangan di Indonesia. Agriekonomika. 6(1), 12-25.

Sethi, D. (2011). Food security in Maldives. Policy Options to Achieve Food Security in South Asia, (274), 161-181. https://doi.org/10.1017/UPO9788175969223.008

Smitha, L. C., Obeidb, A. E. El, \& Jensenb, H. H. (2000). The geography and causes of food insecurity in developing countries. Agricultural Economics, 22, 199-215.

Suryana, A. (2014). Toward Sustainable Indonesian Food Security 2025 : Challenges and Its Responses. FORUM PENELITIAN AGRO EKONOMI, 32(2), 123-135.

Susilowati, S. H. (2014). Attracting the Young Generation to Engage in Agriculture, 1-17. https://doi.org/10.1002/14651858.CD004816.pub4

Toit, D. C. du, Ramonyai, M. D., Lubbe, P. A., \& Ntushelo, V. (2011). Food security. South Africa.

Umair, K., Chen, H., \& Snovia, N. (2017). Comparison of government expenditure and some representative of agricultural product prices and their impact on agricultural growth of pakistan. RJOAS, 3(63), 148-153.

Yu, B., \& You, L. (2013). A typology of food security in developing countries. China Agricultural Economic Review, 5(1), 118-153. https://doi.org/10.1108/17561371311294810 